\title{
Utopie of utiliteit? Enige kanttekeningen bij het debat over een Wereldwijd Parlement van Burgemeesters
}

\section{Slotbeschouwing}

Bas Denters

In zijn slotbeschouwing gaat de hoofdredacteur (en redacteur van het themanummer) kort in op de wenselijkheid en haalbaarheid van een Wereldwijd Parlement van Burgemeesters (WPB). Op beide punten zijn er volgens hem diverse vraagtekens te plaatsen. Op het punt van de wenselijkheid is er nog onvoldoende duidelijkheid over de onderliggende democratieconceptie en over de bijdrage aan de beoogde democratische doeleinden. Op het punt van de haalbaarheid is het de vraag of Barbers hooggestemde verwachtingen over de zegeningen van geavanceerde ICTtools, die worden ingezet voor een virtueel vergaderforum, wel zo realistisch zijn. Een cruciaal punt is ook de financiële en materiële middelen die nodig zijn voor de organisatie en het functioneren van een WPB.

In dit themanummer is een aantal argumenten voor en tegen Barbers voorstel voor een Wereldwijd Parlement van Burgemeesters (WPB) gewisseld. De vraag die $\mathrm{ik}$ hier ter afsluiting van dit themanummer wil bespreken is of het WPB wel of niet utopisch is. Als we een utopie - uit de losse hand en in overeenstemming met het gangbare spraakgebruik - omschrijven als een 'onhaalbaar ideaal' dan impliceert deze beginvraag twee deelvragen. In de eerste plaats rijst de vraag naar de wenselijkheid van een dergelijke nieuwe institutie: is het wel een nastrevenswaardig ideaal? In de tweede plaats roept de beginvraag ook de vraag op naar de haalbaarheid van dit initiatief: is het mogelijk om een dergelijk parlement op te richten en te laten functioneren? In deze slotbeschouwing wil ik rond beide vragen een aantal korte opmerkingen maken.

\section{Is een WPB wenselijk?}

Barber en Corijn hanteren in hun pleidooi hoofdzakelijk twee argumenten om de wenselijkheid van een WPB te beargumenteren. In de eerste plaats verwachten zij dat middels interstedelijke samenwerking - gebaseerd op wereldwijd samenwerkende metropoolregio's met een WPB als sluitstuk - belangrijke stedelijke vraagstukken die zich wereldwijd voordoen, effectiever kunnen worden aangepakt dan in het traditionele model van de statelijke beleidsvoering en interstatelijke afstemming. In de tweede plaats stellen Barber en Corijn dat het (inter)stedelijke model meer mogelijkheden biedt voor een democratische verankering van de besluitvorming over de aanpak van belangrijke maatschappelijke vraagstukken 
dan het (inter)statelijke model. Voor beide argumenten geldt dat ze onvermijdelijk zijn gebaseerd op hypothetische verwachtingen, waarvan pas later (eventueel) kan blijken of ze empirisch houdbaar zijn. Vooralsnog moet worden volstaan met een inschatting van de theoretische plausibiliteit van de redenering die ten grondslag ligt aan de verwachtingen.

Met betrekking tot de effectiviteit is het interstedelijke model gebaseerd op het idee dat er in verschillende steden pragmatisch naar werkbare en werkzame oplossingen, voor problemen die zich wereldwijd voordoen, wordt gezocht en dat lokaal ontwikkelde succesvolle initiatieven zich via interstedelijke netwerken kunnen verspreiden. Het WPB is een nuttig en noodzakelijk sluitstuk, niet omdat dit parlement bindende besluiten kan nemen. Het WPB is in de woorden van Barber (zie dit nummer) 'geen wereldregering' die opereert op basis van 'een model van beheersing en controle'. Het WPB ontleent zijn meerwaarde in het model van interstedelijke samenwerking aan drie zaken: a) anders dan de netwerken is het WPB niet sectoraal maar integraal; b) het WPB kan de ontwikkeling van probleemoplossingen en interstedelijke leerprocessen stimuleren en c) het parlement kan legitimiteit en steun voor de in de netwerken ontwikkelde en te ontwikkelen probleemoplossingen genereren, zodat weerstanden (binnen de steden zelf, binnen landen of internationaal) tegen de implementatie van perspectiefrijke oplossingen kunnen worden overwonnen. Barber spreekt in zijn bijdrage terecht over 'soft governance'. De verwachting is dat deze 'soft governance' in interstedelijke netwerken in elk geval in een aantal gevallen effectiever zal zijn dan (inter)statelijke beleidsvoering gebaseerd op traditionele hiërarchische sturingsinstrumenten (De Bruijn \& Ten Heuvelhof, 1991). Immers, dit type van beleidsvoering staat haaks op de soevereiniteit van de nationale staten en hun vetomacht. Zoals eerder gesteld: over de empirische houdbaarheid van deze verwachtingen kan vooralsnog niets worden gezegd. Vanuit theoretisch perspectief kan worden opgemerkt dat er in elk geval een min of meer plausibele redenering is die aannemelijk maakt dat het interstedelijke model effectief kan zijn. ${ }^{1}$ Het is op basis van deze redenering evenzeer aannemelijk dat het interstedelijke model effectiever kan zijn dan een interstatelijk model althans voor zover men in interstatelijk verband traditionele hiërarchische sturingsmiddelen hanteert. Indien zoals in het verband van de Europese Unie - in het kader van de open coördinatie (De Ruiter, 2007; MacPhail, 2010) - nu reeds regelmatig gebeurt dat men met andere sturingsinstrumenten werkt, is dit minder evident.

Inzake de democratische superioriteit van het interstedelijke model liggen de zaken nog aanmerkelijk ingewikkelder. Barber en Corijn constateren in hun bijdragen terecht dat er in het mondiaal bestuur sprake is van een democratisch gat. Maar, de manier waarop het voorgestelde Wereldparlement dit gat zou moeten dichten, roept veel vragen op. Herweijer formuleert in zijn bijdrage reeds een aantal belangrijke vraagpunten. Zo vraagt hij zich af hoe het in Barbers mondiale democratie zit met de vertegenwoordiging van niet-stedelingen (binnen de metropool- 
regio's en a fortiori in de niet-metropolitane regio's). Verder vraagt hij zich af of burgemeesters in ieder politiek systeem (bijvoorbeeld in Nederland met zijn benoemde gekozen burgemeesters of landen als Zweden of de UK) nou wel de meest aangewezen volksvertegenwoordigers zijn. Ik voeg aan deze vragen nog een aantal vragen toe. In de eerste plaats is de vraag wat voor type democratie Barber en Corijn voor ogen staat als zij hun voorstel voor een WPB formuleren. Kent men eerder werk van Barber - bijvoorbeeld zijn boek Strong Democracy (1984) dan verrast zijn betoog voor een wereldparlement waarin burgemeesters - van naar Italiaans voorbeeld in te stellen metropoolregio's - optreden als stedelijke volksvertegenwoordigers. In dat eerdere werk toonde Barber zich een warm pleitbezorger voor een sterke participatiedemocratie met veel mogelijkheden voor directe burgerparticipatie in de context van veelal kleinschalige gemeenschappen. Dit roept de vraag op hoe de voorstellen voor een democratie op mondiale schaal - gebaseerd op een model van representatieve democratie (door Barber eerder laatdunkend aangeduid als 'thin democracy') in combinatie met grootschalige metropoolregio's (die gezien hun schaal niet bepaald een vruchtbare voedingsbodem vormen voor actief burgerschap; zie: Dahl \& Tufte, 1973; Denters e.a., 2014) als hoofdbestanddelen - zich verhouden tot eerdere denkbeelden van Barber over de inrichting van een betekenisvolle democratie.

Uiteraard - zo moet onmiddellijk worden toegegeven - komt het WPB naast en niet in de plaats van bestaande democratische structuren. En we moeten ook onderkennen dat Barber en Corijn sommige van de problematische kanten van hun voorstellen erkennen en ook proberen deze te ondervangen. Zo stelt Corijn in zijn bijdrage aan dit nummer voor om metropoolregio's niet door één burgemeester (van de centrumgemeente) te laten vertegenwoordigen maar door een delegatie van een bestuurlijk vertegenwoordiger van de centrumgemeente (niet per definitie de burgemeester), een bestuurlijk vertegenwoordiger van de overige regiogemeenten en een vertegenwoordiger van de burgers/de regionale samenleving. Maar zolang er niet meer duidelijkheid bestaat over de manier waarop deze mondiale democratie is ingericht, is het lastig om te bepalen of en in hoeverre hun voorstellen vanuit democratisch opzicht winst op leveren en of ze beter voldoen dan de beperkte, maar welbekende en veelal constitutioneel goed verankerde democratische arrangementen in het (inter)statelijke model.

\section{Is een WPB haalbaar?}

Ook ten aanzien van deze vraag toont Herweijer zich sceptisch. Hij stelt zich de vraag of drukbezette burgemeesters wel voldoende tijd kunnen vrijmaken voor deze nieuwe taak en laten deze verantwoordelijkheden het wel toe om internationaal acte de présence te geven als urgente vraagstukken in de eigen gemeente om aandacht schreeuwen? Met name Barber gaat in zijn bijdrage in op dit punt en ziet een oplossing in de combinatie van echte ('real time) vergaderingen en een geavanceerd virtueel vergaderforum. De vraag is evenwel of zijn hooggestemde verwachtingen over de zegeningen van geavanceerde ICT-tools wel realistisch 
zijn. Recente debacles in ons land bij grote ICT-projecten bij de overheid stemmen in dit opzicht niet bij voorbaat optimistisch.

'Kunnen' deelnemen heeft ook andere aspecten. Herweijer wijst op de Engelse taalvaardigheid van burgemeesters, maar men kan ook denken aan de mogelijkheid dat in elk geval in delen van de wereld burgemeesters geen toestemming zullen krijgen om in den vreemde op te treden als onafhankelijk belangenvertegenwoordiger van de eigen jurisdictie. Op dit moment is het moeilijk voorstelbaar dat burgemeesters van pakweg Nanking, Pyongyang of Minsk - zonder last en ruggenspraak - kunnen afreizen naar een WPB.

Uiteraard is naast 'kunnen' ook 'willen' van belang. Daarmee komen we bij de eigen taak- en rolopvatting van burgemeesters. Deze taak- en rolopvattingen zijn deels persoonlijk, maar worden ook deels bepaald door de politieke structuur waarin burgemeesters opereren. Zo is de vraag wat het effect is van de wijze van aanstelling van burgemeesters. Sterke, direct gekozen burgemeesters zijn met het oog op (her)verkiezing - vanwege een publieke opinie die veelal minder overtuigd zal zijn van de relevantie van buitenlandse 'snoepreisjes' en internationale besognes van de eigen burgemeester - waarschijnlijk minder kosmopolitisch in hun rolopvatting dan hun door de centrale regering benoemde collega's. Is dit wellicht een van de redenen waarom Barbers ideeën over een burgemeestersparlement onder de benoemde burgemeesters van Nederlandse steden zo'n opmerkelijke populariteit genieten?

Naast de genoemde aspecten zijn er met het oog op de haalbaarheid ook meer structurele factoren relevant. Een cruciale vraag is: wie gaat zorg dragen voor de financiële en materiële middelen die nodig zijn voor de organisatie en het functioneren van een WPB? De financiële armslag van de centrumgemeenten in de metropoolregio's is doorgaans beperkt - denk bijvoorbeeld aan Barbers discussie van de casus Detroit. Bovendien zien deze steden zich gesteld voor enorme beleidsopgaven die hun financiële draagkracht veelal te boven gaat - mede vanwege de in Barbers bijdrage gewraakte 'unfunded mandates'. Uiteraard zijn er ook alternatieve bronnen van financiering en facilitering denkbaar. Zo hoopt Barber op ondersteuning van private partijen - bijvoorbeeld IBM, CISCO en Google - bij het realiseren van het voor het WPB noodzakelijke webplatform. Voor een goed functioneren van het WPB is, met het oog op haar legitimiteit, de onafhankelijkheid van het parlement essentieel. De ondersteuning van grote, veelal in de Verenigde Staten gevestigde, bedrijven is daarbij niet zonder risico's. Ook in dit opzicht zijn er dus nog veel open vragen.

\section{Tot besluit}

In deze bijdrage staat de vraag centraal of het idee van een Wereldparlement van Burgemeesters een utopie is.

Op basis van de voorgaande argumenten kunnen we constateren dat Barbers voorstellen in elk geval in één opzicht vooralsnog niet utopisch zijn. Als we - zoals 
in deze bijdrage is gebeurd - een utopie omschrijven als een 'onhaalbaar ideaal', dan hebben we in het voorgaande vastgesteld dat het WPB - project nog tal van belangrijke vragen open laat rond de met name de democratische wenselijkheid van een dergelijk parlement. Zo is nog onvoldoende duidelijk wat de onderliggende democratie-conceptie is en hoe bijvoorbeeld het te hanteren systeem van politieke representatie eruit zal zien. Verder staat te bezien of dit stelsel vervolgens wel bijdraagt aan de boogde democratische doeleinden. Bij de veelal terechte vraagtekens die in dit opzicht worden gezet bij het WPB dient men naar mijn mening echter niet uit het oog te verliezen dat - welke invulling men ook geeft aan het concept democratie - er in de praktische uitwerking en het feitelijk functioneren van zo'n democratie altijd een kloof zal blijven gapen tussen het democratisch ideaal en de feitelijke realisatie daarvan, die altijd zal verschijnen als ' $a$ sorry substitute for the real thing'. Het is precies om die reden dat de onlangs overleden vooraanstaande democratie-theoreticus Robert Dahl (1989) in zijn werk een strikt onderscheid heeft aangebracht tussen de begrippen 'democratie' - verwijzend naar het normatief-theoretisch ideaal - en 'polyarchie' - verwijzend naar de feitelijke institutionele voorzieningen en politieke processen die beogen dit democratisch ideaal te benaderen. Houdt men hiermee geen rekening dan maakt men ongewild het betere de vijand van het goede.

Vooralsnog zijn er ook vraagtekens te plaatsen bij de haalbaarheid van de WPBvoorstellen. In die zin hebben Barbers voorstellen dus nog wel een utopisch karakter. Net als bij de inhoud van de voorstellen, geldt hier dat deze vragen nadere aandacht verdienen. Overigens realiseert Barber zich dat terdege. Hij omschrijft het WPB niet voor niets als een project en hij nodigt burgemeesters en andere practitioners en wetenschappers uit om met hem na te denken over de nadere uitwerking van het concept. Zo vond er in het verlengde van de derde WPB voorbereidingsbijeenkomst (Amsterdam, september 2014) in samenwerking met Bestuurskunde Universiteit Leiden Campus Den Haag een workshop plaats van Benjamin Barber en een aantal experts en wetenschappers (onder wie niet alleen Eric Corijn, maar ook Jouke de Vries, Theo Toonen en schrijver dezes). Daarom is over dit project het laatste woord nog geenszins gezegd.

\section{Literatuur}

Barber, B., Strong democracy. Participatory politics for a new age, Berkeley: 1984.

Bruijn, J.A. de \& E.F. ten Heuvelhof, Sturingsinstrumenten voor de overheid. Over complexe netwerken en een tweede generatie sturingsinstrumenten, Leiden/Antwerpen: 1991.

Dahl, R.A., Democracy and its critics, New Haven/Londen: 1989.

Dahl, R.A. \& E.R. Tufte, Size and democracy, Stanford: 1973.

Denters, B., M. Goldsmith, A. Ladner, P.E. Mouritzen \& L.E. Rose, Size and local democracy, Cheltenham: 2014.

MacPhail, E., 'Examining the impact of the Open Method of Coordination on sub-state employment and social inclusion policies. Evidence from the UK', Journal of European Social Policy, 2010/4, p. 364-378. 
Bas Denters

Ruiter, R. de, To prevent a shift of competence"? Developing the Open Method of Coordination. Education, research and development, social inclusion and e-Europe, dissertatie, European University Institute, Florence: 2007. 